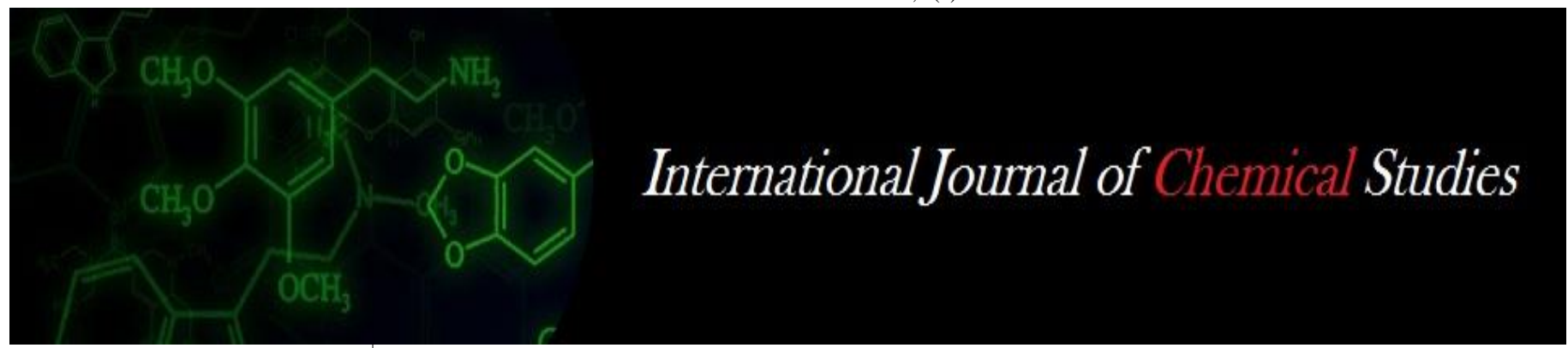

P-ISSN: 2349-8528

E-ISSN: 2321-4902

www.chemijournal.com

IJCS 2020; 8(4): 1617-1620

(C) 2020 IJCS

Received: 07-05-2020

Accepted: 09-06-2020

\section{Ravanachandar A}

Assistant Professor, Dept. of

Horticulture, JKKMCAS, Erode,

Tamil Nadu, India

V Lakshmanan

Professor, Dept. of Vegetable Crops, HC \& RI, Periyakulam.

TNAU, Tamil Nadu, India

\section{Sudhakaran M}

Assistant Professor, Dept. of Environmental Sciences, JKKMCAS, Erode, Tamil Nadu, India
Corresponding Author: Ravanachandar A

Assistant Professor, Dept. of Horticulture, JKKMCAS, Erode, Tamil Nadu, India

\section{Effect of organic manures and biofertilizers on soil enzyme activities under black pepper (Piper nigrum L.)}

\section{Ravanachandar A, V Lakshmanan and Sudhakaran M}

DOI: $\underline{\text { https://doi.org/10.22271/chemi.2020.v8.i4p.9841 }}$

\begin{abstract}
The experiment was conducted to evaluate the effects of organic manures and biofertilizers on soil enzyme activities under Black pepper (Piper nigrum L.) cultivating soils at Horticultural Research Station (TNAU), Yercaud, Salem District. During the study period, the higher available nitrogen content of $168.19 \mathrm{~kg} \mathrm{ha}^{-1}$ was recorded in the treatment $\mathrm{T}_{3}$. Higher avilable phosphorous content of $8.35 \mathrm{~kg} \mathrm{ha}^{-1}$ was recorded in the treatment $T_{2}$ and higher avilable potassium $\left(224.32 \mathrm{~kg} \mathrm{ha}^{-1}\right)$ content was recorded in $\mathrm{T}_{5}$. Among all the treatments, $\mathrm{T}_{5}$ had significantly higher amount of urease, phosphatase and dehydrogenase activities. The combined application FYM, Azospirillum, Phosphobacteria and VAM have a great impact on soil nutrients and enzyme activities under Black pepper (Piper nigrum L.) cultivating soil.
\end{abstract}

Keywords: Organic manures, biofertilizers, soil enzyme, Piper nigrum L.

\section{Introduction}

Soil organic matter affects crop growth and yield, either directly by supplying nutrients or indirectly by modifying the soil physical properties, thereby improving the root environment and thus, stimulating plant growth (Avnimelech 1986) ${ }^{[2]}$. Crop production based on the use of organic manures rather than chemical fertilizers is assumed to be a more sustainable type of agriculture (Chang et al. 2007) ${ }^{[7]}$. Thimmarayappa et al. (2000) ${ }^{[29]}$ indicated that highest yield of spics and total aerial dry matter were associated with the highest organic matter contents of the soils.

Soil enzymes and microbes are plays a major biochemical functions in the overall process of organic matter decomposition in the soil ecosystem (Sinsabaugh \& Moorhead 1994) ${ }^{[22]}$. The activities of an enzyme in soil systems differ in amounts mainly due to the fact that each soil type has different amounts of organic matter content, an intensity of the biological processes and composition and activity of living organisms (Sudhakaran et al. 2018) ${ }^{[25]}$. Soil enzymes are very sensitive to the changes in soil environment due to tillage, amendments, crop rotation and agricultural management practices. Floch et al., (2009) ${ }^{[10]}$ \& Sudhakaran et al. 2019 were also reported that the soil enzyme activities are higher in organically managed farming when compared to the conventional and integrated managed farming.

Black pepper (Piper nigrum L.) is the major spice produced in India. Kerala is the largest producer of black pepper in India with a production of about 25,000 tons, contributing $51 \%$ of the share in the overall production and occupying 95\% area under pepper cultivation (2007-08) followed by Karnataka (37\%) and Tamil Nadu (6\%) (Ravindran 2000) ${ }^{[18]}$. In Tamil Nadu, it is mainly grown in scattered localities on the eastern slopes of the Western Ghats. It is grown as an intercrop in coffee, tea and arecanut plantations especially in Pulney and Shevaroy hills where the vines are trained on shade trees (Balasubramanian 2016) ${ }^{[4]}$.

Since black pepper is usually grown on large scale in virgin soils, it is believed by most of the cultivators that special manuring is not necessary for black pepper (Sayeed,1963) ${ }^{[21]}$. But continuous cropping over a period of years brought about progressive decline in yield, mainly due to depletion of soil fertility. It is therefore absolutely necessary that the crop has to be systematically and judiciously manured to maintain high yield (Kandiannan 2000) ${ }^{[12]}$. 
Nowadays, a lot of attention is being given to biofertilizer application in horticultural crops to reduce the dose of inorganic fertilizers and also reduce the production cost. With the above background, present investigation was proposed with the aim of organic manures and biofertilizers effects on soil enzyme activities under Black pepper (Piper nigrum L.) cultivating soils.

\section{Materials and Methods \\ Study area and Experimental details}

The present investigation on Standardization of Organic Practices in Black Pepper Cv., Panniyur- 1 was carried out at the Horticultural Research Station, Tamil Nadu Agricultural University, Yercaud, Salem District in Tamil Nadu in 200809. The Research Station is situated at an altitude of $1500 \mathrm{~m}$ above MSL between $11^{\circ} 04^{\prime \prime}$ to $11^{\circ} 05^{\prime \prime}$ North latitude and $78^{\circ}$ $05^{\prime \prime}$ to $78^{\circ} 23^{\prime \prime}$ East longitude. The average annual rainfall of Yercaud is $1500 \mathrm{~mm}$ and the mean maximum and minimum temperature are 21.0 to $32.2{ }^{\circ} \mathrm{C}$ and 11.0 to $18{ }^{\circ} \mathrm{C}$, respectively. The mean relative humidity during the period was 58 to 92 per cent. The soil of the experimental plot is laterite in texture with 0.5 to $1.5 \mathrm{~m}$ depth. The $\mathrm{pH}$ of experimental site is 4.5 to 6.0 .

The experiment was laid out in Randomized Block design with consist of six treatments viz, $\mathrm{T}_{1}-\mathrm{FYM} 10 \mathrm{~kg}+5 \mathrm{~kg}$ Coir Compost +50 g Phosphobacteria +50 g Azospirillum, $\mathrm{T}_{2}-$ FYM $10 \mathrm{~kg}+1 \mathrm{~kg}$ Vermi Compost $+50 \mathrm{~g}$ Phosphobacteria, $\mathrm{T}_{3}-\mathrm{FYM} 10 \mathrm{~kg}+1 \mathrm{~kg}$ Neem Cake $+50 \mathrm{~g}$ Phosphobacteria + $50 \mathrm{~g}$ Azospirillum, $\mathrm{T}_{4}-\mathrm{FYM} 10 \mathrm{~kg}+50 \mathrm{~g}$ Azospirillum +50 g Phosphobacteria, T $_{5}-$ FYM $10 \mathrm{~kg}+50 \mathrm{~g}$ Azospirillum +50 $\mathrm{g}$ Phosphobacteria $+200 \mathrm{~g}$ VAM and $\mathrm{T}_{6}-100 \mathrm{~g}$ of $\mathrm{N}+40 \mathrm{~g}$ of $\mathrm{P}_{2} \mathrm{O}_{5}+140 \mathrm{~g}$ of $\mathrm{K}_{2} \mathrm{O}$ (Recommended dose for Package of Practices) - Control

\section{Sample collection and soil parameter analysis}

The soil samples were collected during three different stages viz, before flushing (S1), during peak flowering (S2), after harvest (S3). Soil samples from 0 to $25 \mathrm{~cm}$ depth were collected from four points in the basin, $15 \mathrm{~cm}$ away from the vine and composited to give a sample. Soil samples from all the treatment vines were collected separately. Collected soil samples were air dried, powdered gently and passed through 2 $\mathrm{mm}$ sieve. The samples were kept in labelled polythene bags for further analysis.

Soil $\mathrm{pH}$ (1:2 soil-water suspension) was determined by potentiometry (Bashour \& Sayegh 2007) ${ }^{[5]}$. Available nitrogen was determined by Alkaline permanganate method (Bashour \& Sayegh 2007) [5]. Available phosphorus was determined by modified Olsen method (Olsen \& Sommers 1982) ${ }^{[16]}$. Available potassium was determined by flame photometry (Stanford \& English 1949) ${ }^{[23]}$. Urease activity $\left(\mathrm{mg} \mathrm{NH} \mathrm{NH}_{4}-\mathrm{N} \mathrm{g}^{-1} 2 \mathrm{~h}^{-1}\right.$ ) was measured by ammonia released after the incubation of sample with urea solution for $2 \mathrm{~h}$ at $37{ }^{\circ} \mathrm{C}$ (Tabatabai \& Bremner 1972) ${ }^{[28]}$. Phosphatase activity $(\mu$ moles PNP released $\mathrm{g}^{-1} \mathrm{~min}^{-1}$ ) was estimated by paranitrophenol released after the incubation of soil with $\mathrm{p}$ nitrophenyl phosphate for $1 \mathrm{~h}$ at $37{ }^{\circ} \mathrm{C}$ (Tabatabai \& Bremner $1969)^{[27]}$. Dehydrogenase (DHG) activity ( $\Delta$ in OD at 485 $\mathrm{nm}$ ) was estimated following by Klein et al. (1971) ${ }^{[13]}$.

\section{Results and Discussion}

\section{Effect of organic manures and biofertilizers on soil} nutrient content

The initial nitrogen content in the soil was $156.18 \mathrm{~kg} \mathrm{ha}^{-1}$. At flowering stage, the nitrogen content ranged from $157.72 \mathrm{~kg}$
$\mathrm{ha}^{-1}\left(\mathrm{~T}_{6}\right)$ to $168.19 \mathrm{~kg} \mathrm{ha}^{-1}\left(\mathrm{~T}_{3}\right)$ (Table ). At harvesting stage the range was $135.11 \mathrm{~kg} \mathrm{ha}^{-1}\left(\mathrm{~T}_{6}\right)$ to $153.63 \mathrm{~kg} \mathrm{ha}^{-1}\left(\mathrm{~T}_{3}\right)$. Higher nitrogen content of $168.19 \mathrm{~kg} \mathrm{ha}^{-1}$ was recorded in the treatment $\mathrm{T}_{3}$ at flowering stage and $153.63 \mathrm{~kg} \mathrm{ha}^{-1}$ was recorded in the treatment $T_{3}$ at harvesting stage. $T_{6}$ treatment recorded significantly lower levels of nitrogen in both the stages (157.72 and $\left.135.11 \mathrm{~kg} \mathrm{ha}^{-1}\right)$ at both the stages and the treatments $\mathrm{T}_{4}$ were on par with them (Table 1).

From the initial $7.56 \mathrm{~kg} \mathrm{ha}^{-1}$ the soil phosphorus content was increased to $7.71 \mathrm{~kg} \mathrm{ha}^{-1}$ in $\mathrm{T}_{6}$ and $8.35 \mathrm{~kg} \mathrm{ha}^{-1}$ in $\mathrm{T}_{2}$ at flowering stage (Table 13). The range was $6.90 \mathrm{~kg} \mathrm{ha}^{-1}\left(\mathrm{~T}_{6}\right)$ to $7.44 \mathrm{~kg} \mathrm{ha}^{-1}\left(\mathrm{~T}_{2}\right)$ at harvesting stage. Higher phosphorous content of $8.35 \mathrm{~kg} \mathrm{ha}^{-1}$ was recorded in the treatment $T_{2}$ at flowering stage and 7.44 was recorded in the treatment $T_{2}$ at harvesting stage. $\mathrm{T}_{6}$ treatment recorded significantly lower level of phosphorous (7.71 and $6.90 \mathrm{~kg} \mathrm{ha}^{-1}$ ) at both the stages and the treatments $\mathrm{T}_{4}$ was on par with them (Table 1). The combined application of FYM, Azospirillum, Phosphobacteria and VAM showed greater potassium content $\left(224.32 \mathrm{~kg} \mathrm{ha}^{-1}\right)$ at flowering stage and (206.09 per cent) at harvesting stage. The lower potassium content was observed in $\mathrm{T}_{6}$ (214.20 and 192.11 per cent) at both the stages (Table 1).

Farmyard manure could supply 5.0 Kg N ton ${ }^{-1}$ (Jaipaul, 2011) ${ }^{[11]}$ and Neem Cake contains $5.6 \%$ of N. So the increase in the contents of total nitrogen in the soil might be attributed to the better availability of nitrogen coupled with related nitrification process enabling presence of nitrogen for a longer period in the soil. This is in corroboration with previous findings of Thimmarayappa et al. (2000) ${ }^{[29]}$. Azospirillum would have enhanced the soil available nitrogen because of its non-symbiotic nitrogen fixation. This is in confirmation with earlier observation of Lai (2008) ${ }^{[15]}$. Similarly, Azospirillum might be responsible for the promotion of availability of ion by scavenging the nutrients. The present study is in consonance with the findings of Sathiyavathi and Ramanathan (2001) [20]. Organic nitrogen and $\mathrm{P}_{2} \mathrm{O}_{5}$ availability in the soil increased with the application of FYM, Vermicompost, Azospirillum and Phosphobacteria due to the increase of decomposition of products of organic matter (Sudhakaran et al. 2018) ${ }^{[25]}$. Moreover, vermicompost possesses high ' $P$ ' content. Application of vermicompost in this treatment could be responsible for the high soil ' $\mathrm{P}$ ' content. The inoculation of phosphobacteria resulted in the increased availability of phosphorous, since these bacteria helps to degrade the complex forms of phosphate into more soluble and simple forms of phosphorous. The present investigation is in agreement with that of Basu et al. (2006) ${ }^{[6]}$, Balakrishnan et al. (2007) ${ }^{[3]}$ and Chen \& Liu (2008) ${ }^{[8]}$

The highest potassium content in soil was noticed under the application of FYM along with Azospirillum, Phosphobacteria and VAM. This could be due to the application of FYM, which helps to convert into soil humus substances and mobilization of potassium due to the exchange reaction with soil particles. This is in corroboration with the previous works of Sandhya et al. (2013) ${ }^{[19]}$. Azospirillum may also be ascribed to enhance the availability of potassium. 
Table 1: Effect of organic practices on soil nutrients

\begin{tabular}{|c|c|c|c|c|c|c|c|c|c|}
\hline \multirow{2}{*}{ Treatments } & \multicolumn{3}{|c|}{ Available N $\left(\mathbf{k g ~ h a}^{-1}\right)$} & \multicolumn{3}{c|}{ Available P $\left(\mathbf{k g ~ h a}^{-1}\right)$} & \multicolumn{3}{c|}{ Available K $\left(\mathrm{kg} \mathrm{ha}^{-1}\right)$} \\
\cline { 2 - 10 } & IS & FS & HS & IS & FS & HS & IS & FS & HS \\
\hline $\mathrm{T}_{1}$ & 156.18 & 165.52 & 152.11 & 7.56 & 8.12 & 7.35 & 210.6 & 215.54 & 201.22 \\
\hline $\mathrm{T}_{2}$ & 156.18 & 168.11 & 144.35 & 7.56 & 8.35 & 7.44 & 210.6 & 219.65 & 203.14 \\
\hline $\mathrm{T}_{3}$ & 156.18 & 168.19 & 153.63 & 7.56 & 8.21 & 7.28 & 210.6 & 221.34 & 205.48 \\
\hline $\mathrm{T}_{4}$ & 156.18 & 158.34 & 135.82 & 7.56 & 7.89 & 7.09 & 210.6 & 217.36 & 202.88 \\
\hline $\mathrm{T}_{5}$ & 156.18 & 161.67 & 145.86 & 7.56 & 8.09 & 7.10 & 210.6 & 224.32 & 206.09 \\
\hline $\mathrm{T}_{6}$ & 156.18 & 157.72 & 135.11 & 7.56 & 7.71 & 6.90 & 210.6 & 214.20 & 192.11 \\
\hline $\mathrm{SEd}$ & & 2.3482 & 2.0826 & & 0.1151 & 0.1039 & & 3.1457 & 2.9018 \\
\hline $\mathrm{CD}(\mathrm{P}=0.05)$ & & 5.0052 & 4.4390 & & 0.2454 & 0.2215 & & 6.7050 & 6.1851 \\
\hline
\end{tabular}

IS: Initial Stage, FS; Flowering Stage and HS: Harvesting Stage

\section{Effect of organic manures and biofertilizers on Soil enzyme activities}

Significant difference was observed on urease enzyme activity. $\mathrm{T}_{5}$ registered significantly the higher urease activity of $\left(135.8,146.3\right.$ and $129.2 \mu \mathrm{g} \mathrm{NH}_{4} \mathrm{~N}$ released $\left.\mathrm{g}^{-1} \mathrm{~h}^{-1}\right)$ at initial stage, flowering and harvesting stage respectively. This was followed by $\mathrm{T}_{3}$ which recorded $(131.1,140.9$ and $125.4 \mu \mathrm{g}$ $\mathrm{NH}_{4} \mathrm{~N}$ released $\mathrm{g}^{-1} \mathrm{~h}^{-1}$ ) at initial stage, flowering and harvesting stage respectively (Table 2). Soil urease mainly originate from plant roots and microorganisms, which is influenced by many factors. These include organic matter content of the soil, cropping pattern, soil depth and soil amendments (Acosta-Martinez et al. 2003) ${ }^{[1]}$. Sudhakaran et al. (2018) [25] also reported that urease activity is direct indicator of nitrogen availability in agricultural soils.

Among all the treatments FYM + Azospirillum + Phosphobacteria + VAM $\left(\mathrm{T}_{5}\right)$ showed higher phosphatase activity $\left(0.14,0.14\right.$ and $0.12 \mu$ moles PNP released $\left.\mathrm{g}^{-1} \mathrm{~min}^{-1}\right)$ than absolute control $\left(\mathrm{T}_{6}\right)$ and other treatments and on par with FYM + Azospirillum + Phosphobacteria + Neem cake $\left(\mathrm{T}_{3}\right)$ was given in table 3 . Phosphatase enzyme secreted from plant roots and soil microbes to enhance the solubilization and remobilization of $\mathrm{PO}_{4}$. Phosphatase plays an important role in converting of organic phosphorus to plant liable phosphorus (Chinnadurai et al. 2014).

Significant variation was recorded among the six treatments studied for dehydrogenase activity (Table 2 ). It varied from 0.11 to 0.26 at initial stage, 0.19 to 0.32 at flowering stage and at harvesting stage (0.11 to 0.13$)$. The dehydrogenase activity was high in $\mathrm{T}_{3}(0.26,0.32$ and 0.13$)$ in three stages and it was on par with $\mathrm{T}_{3}$. The dehydrogenase activity was low in $\mathrm{T}_{6}$. This might be due to higher organic manure application which would have favored more microbial populations ultimately more enzyme activity. Similar strong relationship between organic manure and enzyme activities have been reported by Krishnakumar et al. (2005) ${ }^{[14]}$ and Chang et al. (2007) ${ }^{[7]}$.

Table 2: Effect of organic practices on soil enzyme activities

\begin{tabular}{|c|c|c|c|c|c|c|c|c|c|}
\hline \multirow[t]{2}{*}{ Treatments } & \multicolumn{3}{|c|}{$\begin{array}{c}\text { Urease } \\
\left(\mu \mathrm{g} \mathrm{NH}-\mathrm{N} \text { released } \mathrm{g}^{-1} \mathrm{~h}^{-1}\right)\end{array}$} & \multicolumn{3}{|c|}{$\begin{array}{c}\text { Phosphatase } \\
\left(\mu \text { moles PNP released } \mathrm{g}^{-1} \mathrm{~min}^{-1}\right)\end{array}$} & \multicolumn{3}{|c|}{$\begin{array}{c}\text { Dehydrogenase } \\
(\Delta \text { in OD at } 485 \mathrm{~nm})\end{array}$} \\
\hline & IS & FS & HS & IS & FS & HS & IS & FS & HS \\
\hline $\mathrm{T}_{1}$ & 120.00 & 131.6 & 110.9 & 0.13 & 0.21 & 0.10 & 0.18 & 0.25 & 0.18 \\
\hline $\mathrm{T}_{2}$ & 125.70 & 137.1 & 119.0 & 0.18 & 0.29 & 0.15 & 0.15 & 0.23 & 0.15 \\
\hline $\mathrm{T}_{3}$ & 131.1 & 140.9 & 125.4 & 0.21 & 0.32 & 0.19 & 0.23 & 0.29 & 0.22 \\
\hline $\mathrm{T}_{4}$ & 121.0 & 129.4 & 112.0 & 0.16 & 0.24 & 0.13 & 0.14 & 0.21 & 0.13 \\
\hline $\mathrm{T}_{5}$ & 135.8 & 146.3 & 129.2 & 0.25 & 0.39 & 0.20 & 0.26 & 0.32 & 0.25 \\
\hline $\mathrm{T}_{6}$ & 115.3 & 125.0 & 102.3 & 0.11 & 0.25 & 0.08 & 0.11 & 0.19 & 0.11 \\
\hline SEd & 1.7991 & 1.9470 & 1.6818 & 0.0042 & 0.0063 & 0.0033 & 0.0024 & 0.0038 & 0.0014 \\
\hline $\mathrm{CD}(\mathrm{P}=0.05)$ & 3.8346 & 4.1500 & 3.5847 & 0.0090 & 0.0134 & 0.0071 & 0.0050 & \begin{tabular}{|l|l}
0.0081 \\
\end{tabular} & 0.0031 \\
\hline
\end{tabular}

IS: Initial Stage, FS; Flowering Stage and HS: Harvesting Stage

\section{Conclusion}

From the above study, it is concluded that the combined application FYM, Azospirillum, Phosphobacteria and VAM have a great impact on soil nutrients and soil enzyme activities under Black pepper (Piper nigrum L.) cultivating soils. In general, the available $\mathrm{N}, \mathrm{P}$ and $\mathrm{K}$ in the soil, declined from initial stage to harvesting stage indicating the higher uptake of nutrients from the soil as the stages advances. Soil enzyme activity and biomass are influenced the higher biomass and soil enzymes in the treatment FYM, Azospirillum, Phosphobacteria and VAM $\left(\mathrm{T}_{5}\right)$.

\section{Reference}

1. Acosta-Martinez V, Zobeck TM, Gill TE, Kennedy AC. Enzyme activities and microbial community structure in semiarid agricultural soils. Biology and fertility of soils. 2003; 38(4):216-227.
2. Avnimelech Y. Organic residues in modern agriculture. In The role of organic matter in modern agriculture. Springer, Dordrecht, 1986, 1-10.

3. Balakrishnan V, Venkatesan K, Ravindran KC. The influence of halophytic compost, farmyard manure and phosphobacteria on soil microflora and enzyme activities. Plant Soil and Environment. 2007; 53(4):186.

4. Balasubramanian S, Roselin P, Singh KK, Zachariah J, Saxena SN. Postharvest processing and benefits of black pepper, coriander, cinnamon, fenugreek, and turmeric spices. Critical reviews in food science and nutrition. 2016; 56(10):1585-1607.

5. Bashour II, Sayegh AH. Methods of analysis for soils of arid and semi-arid regions. FAO, 2007.

6. Basu M, Mondal P, Basak RK, Basu TK, Mahapatra SC. Effect of cobalt, rhizobium and phosphobacterium inoculations on yield and nutrient uptake in summer groundnut (Arachis hypogaea L.) on alluvial 
soils. Journal of the Indian Society of Soil Science. 2006; 54(1):60-64.

7. Chang EH, Chung RS, Tsai YH. Effect of different application rates of organic fertilizer on soil enzyme activity and microbial population. Soil Science and Plant Nutrition. 2007; 53(2):132-140.

8. Chen Z, Ma S, Liu LL. Studies on phosphorus solubilizing activity of a strain of phosphobacteria isolated from chestnut type soil in China. Bioresource technology, 2008; 99(14):6702-6707.

9. Chinnadurai C, Gopalaswamy G, Balachandar D. Impact of long-term organic and inorganic nutrient managements on the biological properties and eubacterial community diversity of the Indian semi-arid Alfisol. Archives of Agronomy and Soil Science, 2014; 60(4):531-548.

10. Floch C, Capowiez Y, Criquet S. Enzyme activities in apple orchard agroecosystems: how are they affected by management strategy and soil properties. Soil Biology and Biochemistry. 2009; 41(1):61-68.

11. Jaipaul SS, Dixit AK, Sharma AK. Growth and yield of capsicum (Capsicum annum) and garden pea (Pisum sativum) as influenced by organic manures and biofertilizers. Indian Journal of Agricultural Sciences. 2011; 81(7):637-42.

12. Kandiannan K, Sivaraman K, Anandaraj M, Krishnamurthy KS. Growth and nutrient content of black pepper (Piper nigrum L.) cuttings as influenced by inoculation with biofertilizers, 2000.

13. Klein DA, Loh TC, Goulding RL. A rapid procedure to evaluate the dehydrogenase activity of soils low in organic matter. Soil Biology and Biochemistry. 1971; 3(4):385-387

14. Krishnakumar S, Saravanan A, Natarajan SK, Veerabadran V, Mani S. Microbial population and enzymatic activity as influenced by organic farming. Research Journal of Agriculture and Biological Sciences. 2005; 1(1):85-88.

15. Lai WA, Rekha PD, Arun AB, Young CC. Effect of mineral fertilizer, pig manure, and Azospirillum rugosum on growth and nutrient contents of Lactuca sativa L. Biology and fertility of soils. 2008; 45(2):155-164.

16. Olson SR, Somers LE. In A.L. Page (ed.), Methods of soil analysis, Agron. No. 9, part 2: Chemical and microbiological properties, $2^{\text {nd }}$ ed., American Society of Agronomy, Madison, WI, USA. Phosphorus. 1982, 403430.

17. Panse VG, Sukhatme PV. Statistical methods for agricultural workers ICAR Publication. New Delhi, 1967, 259.

18. Ravindran PN. (Ed.). Black pepper: Piper nigrum. CRC Press, 2000.

19. Sandhya A, Vijaya T, Narasimha G. Effect of microbial inoculants (VAM and PSB) on soil physico-chemical properties. Bio Technology: An Indian Journal. 2013; 7(8):320-324.

20. Sathiyavathi R Jancy, Ramanathan N. Mycorrhizal biofertilizers in sustainable agriculture. Spice India, 2001; 14(3):2-5.

21. Sayeed PM. Pepper cultivation. A hand book from Dept. Of Agriculture, Kerala State, Agriculture Information Service, Kerala, 1963.

22. Sinsabaugh RL, Moorhead DL. Resource allocation to extracellular enzyme production: A model for nitrogen and phosphorus control of litter decomposition. Soil biology and biochemistry. 1994; 26(10):1305-1311.
23. Stanford S, English L. Use of Flame photometer in a rapid soil test for K and Ca. Journal of Agronomy. 1949; 41:446-447.

24. Sudhakaran M, Ramamoorthy D, Kumar SR. Impacts of conventional, sustainable and organic farming system on soil microbial population and soil biochemical properties, Puducherry, India. International Journal of Environmental Sciences. 2013; 4(1):28-41.

25. Sudhakaran M, Ramamoorthy D, Savitha V, Balamurugan S. Organic Carbon Stock and its Relationship with Soil Properties in Coastal Agroecosystem of Puducherry, India. J Indian Soc. Coastal Agric. Res. 2018; 36(1):11-17.

26. Sudhakaran M, Ramamoorthy D, Savitha V, Kirubakaran N. Soil Enzyme Activities and Their Relationship with Soil Physico-Chemical Properties and Oxide Minerals in Coastal Agroecosystem of Puducherry. Geomicrobiology journal. 2019; 36(5):452-459.

27. Tabatabai MA, Bremner JM. Use of p-nitrophenyl phosphate for assay of soil phosphatase activity. Soil Biol Biochem. 1969; 1(4):301-307.

28. Tabatabai MA, Bremner JM. Assay of urease activity in soils. Soil Biol Biochem. 1972; 4(4):479-487.

29. Thimmarayappa M, Shivashankar KT, Shanthaveerabhadraiah SM. Effect of organic manure and inorganic fertilizers on growth, yield attributes and yield of cardamom (Elettaria cardamomum Maton). Journal of Spices and Aromatic crops. 2000; 9(1):57-59. 